\title{
Sistem Informasi Terintegrasi Penilaian Beban Kerja Dosen Berbasis Web
}

\author{
Kadek Dwi Loka Samgraha ${ }^{1 *}$, Gede Aditra Pradnyana², I Made Putrama ${ }^{3}$ \\ ${ }^{12}$ Jurusan Teknik Informatika STMIK STIKOM Indonesia \\ ${ }^{3}$ Jurusan Ekonomi dan Akuntansi, Universitas Pendidikan Ganesha
}

\section{A R T I C L E I N F O}

\section{Article history:}

Received 19 January 2019

Received in revised form

10 February 2019

Accepted 12 March 2019

Available online 25 April 2019

\section{Kata Kunci:}

Beban Kerja Dosen, REST

Services, Interoperabilitas,

Laravel, Sistem Terpadu

Undiksha.

Keywords:

Lecturer Workload, REST

Services, Interoperability,

Laravel, Undiksha

Integrated System.
A B S T R A K

Penelitian ini bertujuan untuk: (1) menghasilkan rancangan Sistem Informasi Terintegrasi Beban Kerja Dosen berbasis Web, (2) mengimplementasikan Sistem Informasi Terintegrasi Beban Kerja Dosen berbasis Web, (3) mengetahui respon pengguna terhadap Sistem Informasi Terintegrasi Beban Kerja Dosen berbasis Web. Dalam perancangannya sistem infor- masi ini akan menggunakan teknologi REST (Representional State Transfer) Services dalam pertukaran data untuk menghasilkan sistem yang interoperabilitas. Perancangan dilakukan dengan menggunakan model fungsional berupa UML. Model fungsional berupa UML kemudian diimplementasikan dalam framework Laravel dengan bahasa pemrograman PHP 7.0. Untuk mengetahui respon terhadap Sistem Informasi Terintegrasi Beban Kerja Dosen berbasis Web ini diperoleh dengan metode angket. Hasil akhirnya yaitu berupa (1) Sistem Informasi Terintegrasi Beban Kerja Dosen berbasis Web yang terintegrasi dengan Sistem-sistem Terpadu Undiksha yang dapat diakses menggunakan Web Browser untuk digunakan dalam melakukan penyusunan maupun penilaian Beban Kerja Dosen (BKD) di Universitas Pendidikan Ganesha Singaraja. Dosen hanya perlu menekan satu tombol untuk menyusun BKD tanpa perlu melakukan input data apapun pada sistem. Data BKD didapat dari sistem terintegrasi lain yang dijembatani Sistem Datacenter Undiksha dengan teknologi REST Services. Berdasarkan hasil uji usability, Sistem Informasi Terintegrasi Penilaian Beban Kerja Dosen berasis Web ini mendapatkan presentase hasil sebesar $93 \%$ dengan kategori sangat baik yang berarti dalam pengoperasiannya aplikasi ini mudah untuk digunakan dan dapat berfungsi sesuai dengan fungsi seharusnya.

A B S T R A C T

This study aims to: (1) produce an integrated Information System design for Web-based Lecturer Workload, (2) implement an Integrated Web-Based Lecturer Workload Information System, (3) determine user responses to the Web-based Lecturer Workload Integrated Information System. In designing this information system, REST (Representional State Transfer) Services technology will be used in data exchange to produce an interoperable system. The design is done using a functional model in the form of UML. The functional model in the form of UML is then implemented in the Laravel framework with the PHP 7.0 programming language. To find out the response to the Web-based Lecturer Integrated Workload Information System, the questionnaire method was obtained. The end result is in the form of (1) Integrated Information System for Web-Based Lecturer Workload that is integrated with Undiksha Integrated Systems that can be accessed using a Web Browser for use in compiling or evaluating Lecturer Workload (BKD) at Ganesha Singaraja Educational University. Lecturers only need to press one button to compile BKD without the need to input any data on the

\footnotetext{
Corresponding author.

E-mail addresses: lokasamgraha@gmail.com (Kadek Dwi Loka Samgraha)
} 
system. BKD data is obtained from another integrated system which is bridged by the Undiksha Datacenter System with REST Services technology. Based on the usability test results, the Integrated Information System for Workload Assessment of Web-Based Lecturers has a percentage of results of $93 \%$ with a very good category which means that in operation the application is easy to use and can function in accordance with the functions it should ...

Copyright (@ Universitas Pendidikan Ganesha. All rights reserved.

\section{Pendahuluan}

Dosen dinyatakan sebagai pendidik professional dan ilmuan dengan tugas utama mentransformasikan, mengembangkan, dan menyebarluaskan ilmu pengetahuan, teknologi, dan seni melalui pendidikan, penelitian, penelitian dan pengabdian kepada masyarakat [1]. Dosen merupakan salah satu komponen esensial dalam suatu sistem pendidikan perguruan tinggi. Peran, tugas, dan tanggung jawab dosen sangat penting dalam mewujudkan tujuan pendidikan nasional, yaitu mencerdaskan kehidupan bangsa, meningkatkan kualitas manusia Indonesia, yang meliputi iman/takwa, ahlak mulia, dan penguasaan ilmu pengetahuan, teknologi dan seni, serta mewujudkan masyarakat Indonesia yang maju, adil, makmur, dan beradab [2].

Kompetensi tenaga pendidik, khususnya dosen, diartikan sebagai seperangkat pengetahuan, keterampilan dan perilaku yang harus dimiliki, dihayati, dikuasai, dan diwujudkan oleh dosen dalam pelaksanaan tugas profesionalnya. Kompetensi sosial dan kompetensi profesional. Tugas utama dosen tercantum pada Pedoman Beban Kerja Dosen dan Evaluasi Pelaksanaan Tridharma Perguruan Tinggi oleh Direktorat Jendral Pendidikan Tinggi Departemen Pendidikan Nasional 2010 yang diantaranya yaitu melaksanakan tridharma perguruan tinggi dengan beban kerja paling sedikit sepadan dengan 12 (dua belas) SKS dan paling banyak 16 (enam belas) SKS pada se- tiap semester sesuai dengan kualifikasi akademik.

Pelaksanaan tugas utama dosen ini perlu dievaluasi dan dilaporkan secara periodik sebagai bentuk akuntabil- itas kinerja dosen kepada para pemangku kepentingan. Kompetensi dosen nantinya akan menentukan kualitas pelaksanaan Tridharma Perguruan Tinggi sebagaimana yang ditunjukkan dalam kegiatan profesional dosen. Un- tuk menjamin pelaksanaan tugas dosen berjalan sesuai dengan kriteria yang ditetapkan dalam peraturan perun- dang - undangan maka perlu dievaluasi setiap periode waktu yang ditentukan [2].

Melalui wawancara dengan beberapa dosen di Jurusan Pendidikan Teknik Informatika Undiksha, ditemuka beberapa permasalahan dalam pengisian BKD secara manual diantaranya yaitu, banyak dosen yang masih men- galami masalah karena bingung dalam perhitungan skor apabila diisi secara manual, karena terkait dengan be- berapa bidang. Penyusunan BDK memakan waktu yang lama karena dosen harus memperhatikan setiap kompo- nen BKD pada panduan dan melakukan perhitungan secara mandiri. Belum terkomputerisasinya data yang diisi oleh masing-masing dosen, sehingga mengakibatkan data BKD yang sudah dikumpulkan oleh masing-masing dosen dapat saja hilang. Pegawai yang ditugaskan menangani data-data tersebut juga bisa saja posisinya diganti oleh pegawai yang lain.

Ada beberapa penelitian yang berkaitan dengan penelitian yang akan dikembangkan oleh peneliti. Adapun yang pertama adalah penelitian yang dikembangkan oleh Agus Aan Jiwa Permana dengan judul, "Sistem Infor- masi Beban Kerja Dosen Fakultas Teknik dan Kejuruan Undiksha", pada tahun 2016. Menyatakan bahwa dengan mengembangkan sebuah sistem BKD online maka pengisian data BKD dapat diisi tanpa terbatas ruang dan waktu. Data yang disimpan menjadi mudah untuk dikelola dan dievaluasi oleh asesor. Sistem belum terin- tegrasi dengan sistem lain dan masih mengandalkan data inputan BKD secara manual oleh dosen yang ber- sangkutan.

Penelitian lain terkait pengembangan sistem informasi BKD juga dilakukan oleh I Gede Made Karma ber- sama Jeni Susanti dengan judul "Pengembangan Sistem Informasi Beban Kerja Dosen (BKD) untuk Pelaporan Pelaksanaan Tridharma Perguruan Tinggi", pada tahun 2014. Menghasilkan sistem yang dapat dipergunakan untuk melakukan proses pencatatan, pengelolaan dan pelaporan kegiatan Tridharma. Sistem dikelola langsung oleh staf jurusan dan dosen. Staf jurusan mencatatkan kegiatan yang diselenggarakan jurusan, sedangkan dosen kegiatan personalnya. Sistem menggunakan metode penyusunan BKD secara manual pada sistem.

Penelitian terkait berikutnya berjudul, "Perancangan dan Implementasi Sistem Monitoring BKD (Beban Kerja Dosen) Berbasis Web di Jurusan Ilmu Komputer Universitas Udayana", tahun 2015 oleh A.A Lawa Iswara Putra. Metode yang digunakan dalam pengembangan sistem adalah metode waterfall. 
Penelitian ini bertujuan untuk memudahkan kepala jurusan dalam melakukan pengawasan penyelesaian beban kerja dosen dalam melakuka kegiatas tugas yang telah direncanakan sebelumnya. Sistem yang dikembangkan masih mengandalkan data inputan komponen BKD secara manual oleh dosen untuk disimpan didalam database sistem dan belum ber- sifat interoperabilitas.

Berdasarkan permasalahan dan yang disampaikan serta melihat penelitian-penelitian terdahulu, peneliti ter- tarik untuk mengangkat suatu penelitian yang berjudul "Pengembangan Sistem Informasi Terintegrasi Penilaian Beban Kerja Dosen berbasis Web" dengan studi kasus Universitas Pendidikan Ganesha. Dalam pengembangan dan implementasinya nanti sistem ini diharapkan dapat mengurangi kesulitan penyusunan beban kerja dosen, menyeragamkan perhitungan beban kerja dosen dan proses penilaian dapat konsisten karena akan terintegrasi dengan sistem-sistem pendukung. Guna menghasilkan sistem yang mendukung interoperabilitas, ter- hubung satu sama lain untuk dapat saling bertukar informasi.

Sistem yang sudah ada (existing system) dan siap medukung Sistem BKD diantaranya adalah (1) Sistem Da- ta Center, adalah sistem yang menjadi pusat data dari setiap sistem terintegrasi. Sistem terintegrasi melakukan sinkronisasi data melalui layanan web services baik itu mengirim data maupun mengambil data. (2) SSO (Single Sign On), adalah sistem yang menjadi pintu utama dari setiap sistem terintegrasi. Dengan login pada sistem SSO, user dapat mengakses setiap sistem terintegrasi lainnya. (3) DOSEN, adalah sistem yang menjadi pusat data dosen Undiksha baik dosen tetap maupun dosen kontrak. Sistem melakukan import data dosen dari feeder DIKTI. Setiap dosen dapat melakukan perubahan datanya pada sistem. (4) PEGAWAI, adalah sistem yang menjadi pusat data pegawai Undiksha baik pegawai tetap maupun pegawai kontrak. Setiap pegawai dapat melakukan perubahan datanya pada sistem. (5) SHAKUNTALA (Sistem Informasi Hukum dan Tata Laksana), adalah sistem yang men- jadi pusat data dari setiap SK (Surat Keterangan) yang berlaku di Undiksha seperti SK mengajar, SK sebagai Dekan dan lain-lain. Sistem-sistem yang sudah ada nantinya akan saling berhubungan melalui sistem Data Cen- ter sebagai pangkalan data. Dijembatani oleh layanan web service dengan teknologi REST (Representional State Transfer), sistem BKD maupun sistem lainnya akan dapat memanfaatkan data-data antar sistem guna mengurangi inkonsistensi dan redundansi data yang muncul. adalah template untuk Microsoft Word versi 6.0 atau di atasnya.

\section{Metode}

\section{A. Fase Pemodelan Bisnis}

Evaluasi Beban Kerja Dosen secara periodik memerlukan suatu panduan yang dapat digunakan untuk me- nyeragamkan penyusunan maupun penilaian beban kerja setiap dosen. Dalam mencari garis besar alur penyusu- nan maupun penilaian Beban Kerja Dosen, peneliti melakukan library research dan wawancara dengan pemangku kepentingan di Universitas Pendidikan Ganesha. Adapun hasil yang diperoleh dari library research adalah Buku Pedoman Perhitungan Beban Kerja Dosen yang disusun oleh Universitas Pendidikan Ganesha Singaraja tahun 2016. Pedoman ini mencangkup segala hal yang berhubungan dengan kegiatan penyusunan dan penilaian beban kerja dosen yaitu: (1) Dasar pelaksanaan penyusunan dan penilaian Beban Kerja Dosen, (2) Landasan Hukum, (3) Unsur-unsur yang harus dilengkapi dalam penyusunan beban kerja dosen (pendidikan, penelitian, pengabdian, dan penunjang), (4) Asesor dan peranannya dalam evaluasi beban kerja dosen, serta (5) alur pelaksanaan evaluasi beban kerja dosen.

B.Fase Pemodelan Data

Sistem ini akan menggunakan database MySQL sebagai tempat penyimpanan datanya. Pemodelan data yang dil- akukan pada penelitian ini antara yaitu (1) Perancangan Entity Diagram dan (2) Perancangan Basis Data.

C. Fase Pemodelan Proses

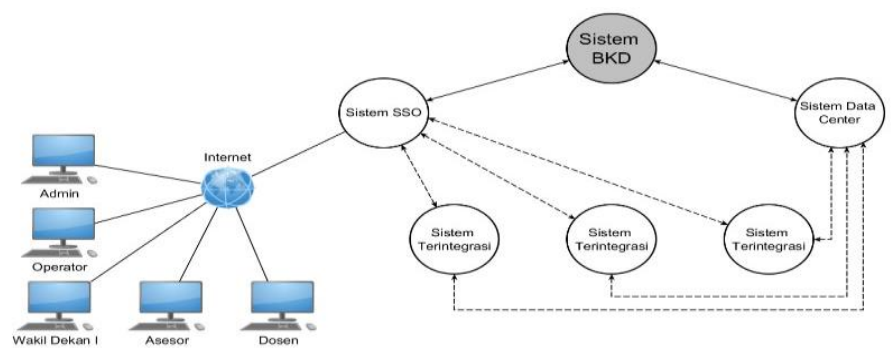

Gambar 2 Rancangan Arsitektur Perangkat Lunak 
Rancangan arsitektur aplikasi yang dibangun menggunakan konsep intereporabilitas. Dimana setiap sistem akan saling berkomunikasi menggunakan layanan web service yang disediakan oleh Data Center dengan teknologi REST atau Representional State Transfer. Mekanismenya adalah sebagai berikut : (1) Sistem Data Center akan mendaftarkan setiap sistem yang perlu melakukan sinkronisasi data termasuk sistem BKD untuk memperoleh username dan password untuk akses API masing-masing sistem. (2) setelah memperoleh username dan password Sistem BKD akan mengirim form yang memuat data username dan password dimana nantinya akan diferivikasi oleh Sistem Data Center untuk menetukan apakah request mendapat akses API atau tidak. (3) Sistem Data Center akan me-return hasil ferivikasi, apabila tidak memperoleh akses maka Sistem BKD akan mendapatkan error code dari Sistem Data Center, apabila memperoleh akses maka Sistem BKD akan mem- peroleh token untuk mengakses API yang sudah disediakan. (4) Sistem BKD akan mengakses URL API dengan token hasil ferivikasi untuk memperoleh data yang dibutuhkan berbentuk JSON. Terakhir (5) data JSON akan diolah oleh Sistem BKD sebelum disimpan pada database sistem.

D. Fase Pembuatan Aplikasi

Aplikasi yang telah dirancang nantinya akan terintegrasi secara langsung dengan dengan beberapa sistem yai- tu sistem Single Sign On (SSO) Undiksha untuk validasi login pengguna dan sistem Data Center untuk melakukan sinkronisasi data dosen, dan komponen BKD dimana sistem Data Center akan mengumpulkan data dari sistem-sistem terpadu lainnya guna memenuhi kebutuhan data dari sistem BKD.

Pengembangan aplikasi versi web akan dilakukan dengan menggunakan web service sebagai protokol komu- nikasi dengan sistem Data Center, Framework Laravel yang berbasis PHP dan MySQL sebagai databasenya. Selain menggunakan web service, Framework Laravel dan MySQL, penulis juga menggunakan HTML5, CSS3, Framework Bootstrap, dan Javascript terutama dalam membuat desain dan layout halaman web.

E.Fase Pengujian dan Turnover

Pengujian yang dilakukan berupa pengujian Whitebox yaitu pengujian secara langsung terhadap struktur pro- gram dari sistem yang dibuat oleh developer atau peneliti sendiri. Adapun jenis whitebox testing yang dilakukan adalah basis path testing.

Pada pengujian Blackbox dilakukan dengan menggunakan teknik boundary value testing. Boundary value test-ing merupakan teknik desain testing yang paling dasar. Teknik ini membantu tester untuk memilih subset yang kecil untuk membuat test case yang mungkin. Yang menjadi fokus pada teknik ini adalah batasan-batasan yang simple karena pada hal tersebutlah kebanyakan cacat pada perangkat lunak tersembuyi [4]

\section{Hasil dan pembahasan}

Implementasi perangkat lunak Sistem Informasi Terintegrasi Penilaian Beban Kerja Dosen berbasis Web meliputi lingkungan implementasi perangkat lunak, batasan implementasi perangkat lunak, implementasi arsitektur perangkat lunak, dan implementasi struktur data perangkat lunak serta implementasi layar antarmuka perangkat lunak.

Dalam pengujian perangkat lunak Sistem Informasi Terintegrasi Penilaian Beban Kerja Dosen berbasis Web akan dibahas mengenai tujuan pengujian dari perangkat lunak, tata ancang dan teknik pengujian perangkat lunak, pelaksanaan pengujian perangkat lunak, dan evaluasi hasil pengujian perangkatlunak.

A. Implementasi Antarmuka Perangkat Lunak

1. Antarmukan Dashboard Dosen akan tampil ketika dosen berhasil login pada sistem SSO (Single Sign On) Undiksha. Antarmukan dashboard dosen ditunjukkan pada Gambar 3. 


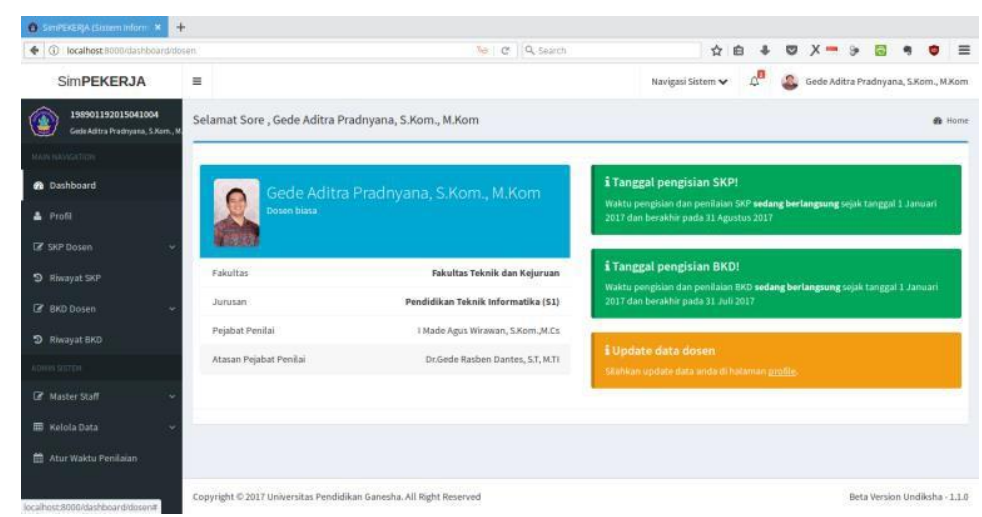

Gambar 3 Implementasi Antarmuka Dashboard Dosen

2. Antarmuka Profil Dosen merupakan antarmuka yang menampilkan data-data dosen. Dosen juga dapat melakukan update data diri dengan menekan tombol sinkronisasi. Antarmukan profil dosen ditunjukkan pada Gambar 4.



Gambar 4 Implementasi Antarmuka Profil Dosen

3. Antarmuka Penyusunan BKD merupakan antarmuka yang menampilkan status penyusunan BKD pada periode penilaian yang sedang aktif. Antarmuka penyusunan BKD ditunjukkan pada Gambar 5.

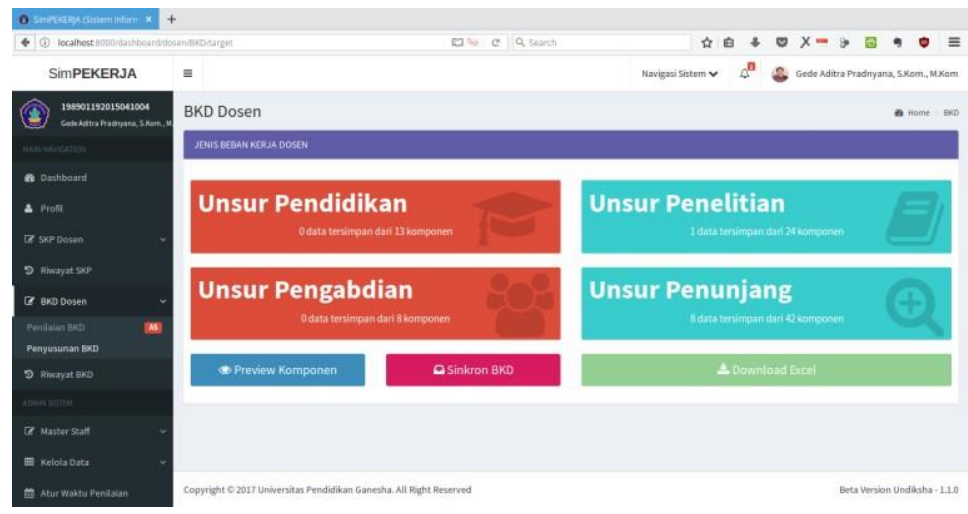

Gambar 5 Implementasi Antarmuka Penyusunan BKD

4. Dosen juga dapat melakukan sinkronasi komponen BKD secara keseluruhan melalui halaman awal penyusunan BKD dengan menakan tombol "Sinkron BKD" yang ditunjukkan pada Gambar 6. 




Gambar 6 Implementasi Proses Sinkronisasi

BKD

5. Ketika dosen sudah selesai menyusun BKD, dosen dapat meminta BKD nya dinilai oleh Asesor BKDyang sudah ditentukan sebelumnya oleh Wakil Dekan I yang ditunjukkan pada Gambar 7.

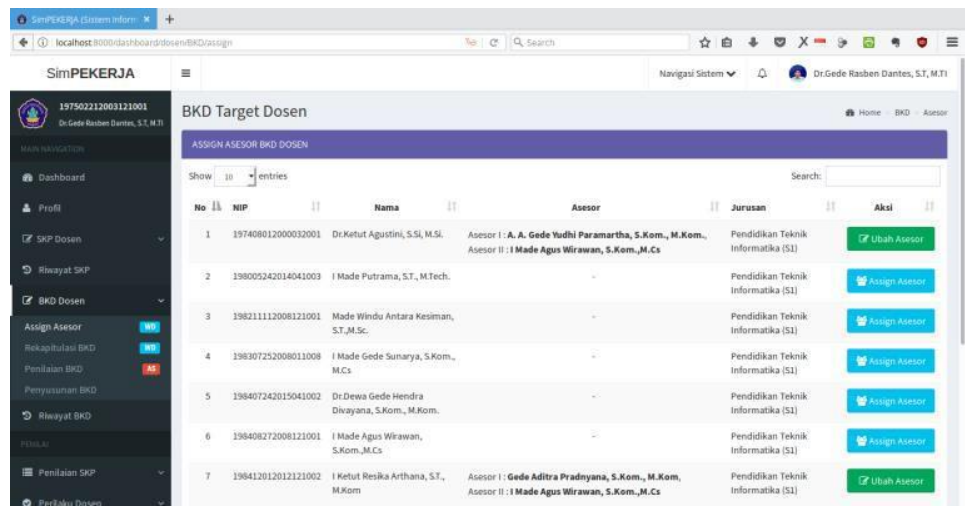

Gambar 7 Implementasi Assign \& Update Asesor BKD

6. Antarmuka Hasil File Excel BKD menampilkan identitas dosen beserta setiap komponen BKD yang disusun dan sudah dinilai oleh Asesor. File Excel diproteksi oleh password agar tidak dapat diubah. Antarmuka dapat dilihat pada Gambar 8.



Gambar 8 Implementasi File Excel BKD

7. Antarmuka Penilaian Capaian Komponen BKD manampilkan rekap BKD dosen yang dinilai. Setiap kom- ponen yang disusun dosen akan dapat dinilai oleh asesor yang ditunjuk. Asesor dapat melihat bukti untuk menetukan nilai capaian setiap komponen BKD disusun yang ditunjukkan pada Gambar 9. 


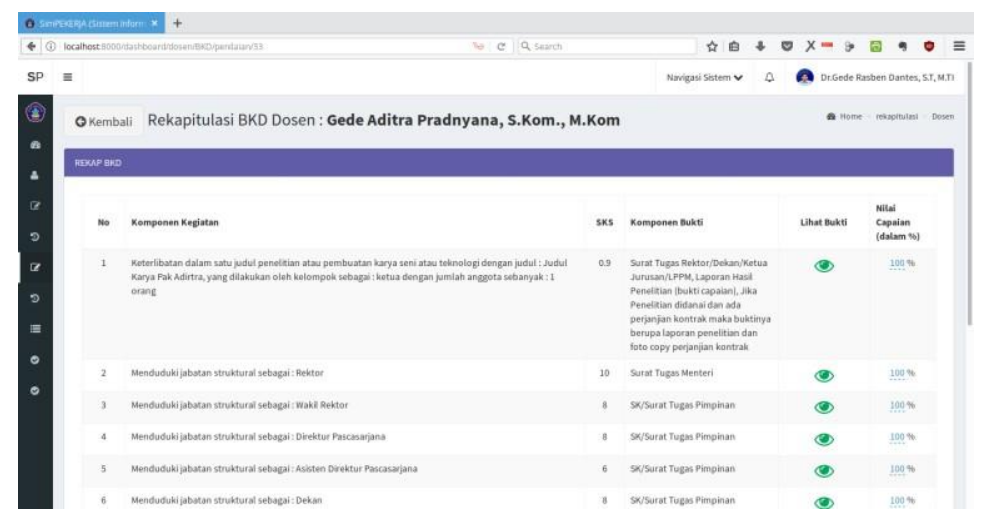

Gambar 9 Implementasi Penilaian BKD

\section{B. Pengujian Perangkat Lunak}

Dalam pengujian perangkat lunak Sistem Informasi Terintegrasi Penilaian Beban Kerja Dosen berbasis Web akan dibahas mengenai tujuan pengujian dari perangkat lunak, tata ancang dan teknik pengujian perangkat lunak, pelaksanaan pengujian perangkat lunak, dan evaluasi hasil pengujian perangkatlunak.

Adapun hasil dari pengujian yang dilakukan pada sistem memperoleh hasil Secara keseluruhan pelaksanaan pengujian perangkat lunak berlangsung dengan lancar, baik saat pengujian kotak hitam (blackbox testing), pen- gujian kotak putih (whitebox testing), pengujian keakurasian sistem, dan pengujian kesesuaian sistem. Berdasar- kan hasil pengujian blackbox (pengujian fungsionalitas) diperoleh bahwa proses yang dijalankan oleh pengguna telah mampu berjalan dengan baik. Kemudian, berdasarkan hasil pengujian whitebox (prosedural) diperoleh bahwa pengimplementasian algoritma telah berhasil. Selanjutnya, berdasarkan dari hasil pengujian ahli media tersebut dapat dinyatakan bahwa semua proses yang ada dalam Sistem Informasi Terintegrasi Penilaian Beban Kerja Dosen berbasis Web sudah layak uji coba tanpa revisi. Kemudian, dari pengujian usability tersebut dapat dinyatakan bahwa Sistem Informasi Terintegrasi Penilaian Beban Kerja Dosen berbasis Web memiliki kualitas dari segi aspek learnability 97\%, efficiency $89 \%$, memorability 93\%, error $96 \%$, dan satisfaction $90 \%$. Hasil uji respon dapat dinyatakan bahwa respon pengguna sebesar $93 \%$ atau dapat dinyatakan mendapat respon yang sangat baik

\section{Simpulan dan saran}

Sistem Informasi Terintegrasi Penilaian Beban Kerja Dosen berbasis Web menggunakan metodelogi penelitian pengembangan perangkat lunak SDLC (System Development Life Cycle) dengan mengikuti tahapan pembuatan sesuai dengan model RAD (Rapid Application Development). Pada fase pemodelan bisnis, peneliti melakukan studi literatur dan berkonsultasi dengan pembimbing. Selanjutnya pemodelan data peneliti menggunakan MySQL sebagai tempat penyimpanan data. Hasil analisis yang telah dilakukan sebelumnya pada fase pemodelan bisnis dilanjutkan dengan merancang pemodelan proses dari perangkat lunak, menggunakan kon- sep arsitektur sistem yang interoperabilitas, dan pemodelan activity diagram. Dilanjutkan dengan perancangan antarmuka sebelum dilakukannya implementasi.

Implementasi perangkat lunak Sistem Informasi Terintegrasi Penilaian Beban Kerja Dosen berbasis Web terdiri dari lingkungan implementasi perangkat lunak, batasan implementasi perangkat lunak, implementasi arsi- tektur perangkat lunak, dan implementasi struktur data perangkat lunak. Adapun Bahasa pemrograman yang diimplementasikan pada Sistem Informasi Terintegrasi Penilaian Beban Kerja Dosen berbasis Web teridiri dari PHP, HTML 5, CSS3, dan Javascript dan datavase server yang digunakan adalah MySQL.

Pengujian Sistem Informasi Terintegrasi Penilaian Beban Kerja Dosen berbasis Web dilakukan dengan be- berapa cara dan mendapatkan hasil sebagai berikut. Berdasarkan hasil pengujian blackbox (pengujian fungsional- itas) diperoleh bahwa proses yang dijalankan oleh pengguna telah mampu berjalan dengan baik. Kemudian, ber- dasarkan hasil pengujian whitebox (prosedural) diperoleh bahwa pengimplementasian algoritma telah berhasil. Selanjutnya, berdasarkan dari hasil pengujian ahli media tersebut dapat dinyatakan bahwa semua proses yang ada dalam Sistem Informasi Terintegrasi Penilaian Beban Kerja Dosen berbasis Web sudah layak uji coba tanpa revi- si. Kemudian, dari pengujian usability tersebut dapat dinyatakan bahwa Sistem Informasi Terintegrasi Penilaian Beban Kerja Dosen berbasis Web memiliki kualitas dari segi aspek learnability 97\%, efficiency $89 \%$, memorabil- ity 93\%, error 96\%, 
dan satisfaction $90 \%$. Hasil uji respon dapat dinyatakan bahwa respon pengguna sebesar $93 \%$ atau dapat dinyatakan mendapat respon yang sangat baik.

\section{Daftar Rujukan}

Abdul, K. (2003). Pengenalan Sistem Informasi . Yogyakarta: Andi.

DEPKOMINFO (2010). Kerangka Acuan dan Pedoman Interoperabilitas Sistem Informasi Instansi Pemerintah. Direktorat Sistem Informasi, Indonesia : Perangkat Lunak dan Konten Direktorat Jendral Aplikasi Telematika Departe- men Komunikasi dan Informatika.

N. R. I. Indonesia, Undang - undang Nomor 14 Tentang Guru dan Dosen (Bab 1 Pasan 1 ayat 2), 2005.

Safi, M., Santosa, P. I., \& Ferdiana, R. (2016). PENGEMBANGAN SISTEM INFORMASI SUMBERDAYA SEKOLAH KOTA TERNATE BERBASIS WEB DENGAN METODE RAPID APPLICATION DEVELOPEMENT. Jurnal POSITIF, 34.

S. McCool, Laravel Starter, Birmingham: Packt Publishing, 2012.

"Swagger," [Online]. Available: https://swagger.io. [Accessed 3 Maret 2017].

U. P. Ganesha, Pedoman Penilaian Beban Kerja Dosen, 2016.

U. P. Ganesha, Pedoman Penilaian Beban Kerja Dosen, 2016.

U. P. Ganesha, Pedoman Penilaian Beban Kerja Dosen, 2016.

WWW, "Konsorsium WWW". 2004 